\title{
THE CONCEPT OF RULE OF LAW AND THE NOTION OF JUSTICE IN THE SURVIVAL OF THE NIGERIAN STATE
}

AYODELE, JOHN ALADE,

(Received 26 March 2021, Revision Accepted 11 May 2021)

\begin{abstract}
Upholding the rule of law and adherence to the principles of justice play an important role in the economic and social development of a Nation, this is because rule of law and justice to all guarantee peace, security and stability. For a Nation to be ranked among the committee of civilized and developed Nations, rule of law and principles of justice must be upheld. Using the doctrinal methodology, this work assessed Nigerian State from the perspective of her adherence to the rule of law and upliftment of justice. This work reaffirms that for Nigeria as a State to achieve the Sustainable Development Goal 16, will depend on her commitment to the notion of the ideal character of the rule of law as a guiding principle for organizing life in society and access to justice as the essential instrument for the protection of human right. The work concluded that upholding law and order, providing predictable and efficient judgments through the institutional framework and attributes believed necessary to actuate the rule of law such as well trained law enforcement officers, functional courts, independent judiciary, comprehensive law and equipped correctional facilities and homes are the things upon which the Nigerian state can continue, prosper and survive.
\end{abstract}

KEYWORDS: Rule of law, notion of justice, Nigerian State.

This is a revised version of the paper delivered at the $6^{\text {th }}$ Biennial International Conference organized by Centre for Peace and Strategic Studies, University of Ilorin held between the $24^{\text {th }}-27^{\text {th }}$ November, 2019

\subsection{INTRODUCTION}

All the United Nations member States in 2015 adopted the 2030 agenda for Sustainable Development Goals SDG. This document provides the blueprint for peace and prosperity for people and the planet now and into the futures. These SDGs are 17 in number. Goal 16 aims at ending violence, promoting the rule of law, strengthening institutions and increasing access to justice. Law, justice, peace and security - these are what it takes to build a good society; a nation where no man is oppressed 'a nation blest with peace and plenty (Oputa, 1990).
The attainment of law, justice, peace, economic development and security is the primary objective of any Nation as provided for in sections 14-18 of the 1999 Constitution of Nigeria. To attain this objective, the rule of law must be observed. This is because if we are not ruled by law, we have to be ruled by men and man is an extremely unpredictable animal (Oputa, 1989).

The rule of law is touted as able to accomplish everything: from improving human rights to enabling economic growth, improved and conducive business environment to helping to win war on terrors (Belton, 2005). The term rule of law is complex in nature because it has no

\footnotetext{
Ayodele, John Alade, General Studies Department, Lagos State Polytechnics Ikorodu, Lagos State, Nigeria
} 
precise legal definition (Shyllon \& Obasanjo, 1980), however, a robust examination of rule of law shall be provided in the course of the work. Justice on the other hand is a very wide concept and it is the underlying formulation of human togetherness. It has been said that no Nation can sail on an even keel without justice (Oputa, 1989). Justice is the pivot upon which checks and balances of all governmental organs and agencies rotate.

Justice and the rule of law compliments one another, as such, the survival of any Nation (Nigeria inclusive) depend largely on the adherence to the rule of law and notion of justice. Survival in this sense relates to security, the continuous and peaceful co-existence of the various ethnic group, socio-economic development, infrastructural and human developments etc.

This work will focus on the explanation and meaning of the rule of law and the notion of justice with the Nigerian nation in focus. How the continuous growth and survival of Nigeria as a nation will depend largely on these concepts. In achieving this aim, this work will be divided into four parts. Part one will be the introductory part, part two will take an in-depth look at rule of law and the notion of justice. Part three discusses the application and observance of the rule of law and justice in Nigeria while part four will be the concluding part made up of recommendation and conclusion.

2.0 The rule of law and notion of justice

Rule of law can be described as the absolute or predominance of supremacy of the ordinary law of the land over all citizens irrespective of how powerful (Akeredolu, 2008). Rule of law include the supremacy of the law as opposed to arbitrariness or even wild discretion by governments, the equality of all persons before the law and establishing the rights of individuals developed by case law, it is government by laws not by men (Stein, 2009).

In the case of Shugaba v. Minister of Internal Affairs (1981), the Court held that rule of law ensures equality of all persons without any distinction, that it also guarantees transparency and incorruptibleness and must be preferred. Therefore, for there to be a viable and meaningful constitutional democracy, the rule of law must be the pivot on which that constitutional democracy rotates. Rule of law itself is a multi-dimensional concept in the sense that apart from the fact that the exact meaning cannot be provided (Rosenfeld, 2001), it requires that State only subject the citizenry to publicly promulgated laws, that the State's legislative functions be separate from the adjudicative functions and that no one within the polity be above the law (Rosenfeld, 2001). Thus, rule of law depend largely on the operational value the doctrine of separation of power is accorded.

For the rule of law to exist, the laws with which all persons are to be governed on equal terms must have been made by the legislative arm of the government which is the arm saddled with the responsibility to make laws or those that the power to make law must have been delegated to and the said laws must be known by the people. Rule of law will thrive where laws are made bearing in mind the dignity, respect, equality and rights of the citizenry are considered and guaranteed (Rosenfeld, 2001). The rule of law entails a functional, efficient effective independent and incorruptible judiciary; a system put in place to advise all persons of their rights in seeking redress of grievances without fear.

The ideal meaning of rule of law that can be discerned from its characteristics which according to Stein (2009) are.

1. The law is superior to all members of the society, including government officials vested with legislative, executive or judicial power.

2. The law is known, stable and capable of being predicated and applied equally to all persons in like circumstances.

3. Members of society have the right to participate in the creation and refinement of laws that regulates their behaviours.

4. The law is just and protects human rights and dignity of all members of the society.

5. Judicial power is exercised independently of either the executive or legislative arms and individual judges base their decisions solely on facts and law as applicable to individual cases.

Justice is not only a pre-requisite but the cornerstone upon which peace and harmony in any society is built. It is ironic that important concept like justice has no unified definition yet for any law to have any meaning, it must have as its goal the attainment of justice. This is because law is not an end in itself, but justice is (Aguda 1985).

Justice demands that freedom, equity and other basic rights be accorded and secured to human being to the greatest extent consistent with the common good (Bodemheimer, 1962). Justice is an essential indispensable core value in any organized, civilized human society (Badamasiuy \& Bello, 2013). The functional importance of law should be to produce justice; justice has 
therefore been defined as that virtue which accepts every human being as person and not as a thing and then renders to each such person his or her due (Oputa, 1990). In a loose sense, justice implies equity and fairness which guarantee the implementation and realization of basic fundamental human rights as provided for by the constitution.

2.1 Rule of law and notion of justice in Nigeria Since 1999, Nigeria has been ruled by a democratically elected government; democracy being government of the people by the people and for the people. As a result of this, the doctrine of separation of power as entrenched in the 1999 Constitution of Nigeria is expected to be observed.

At the Federal level, the legislative house comprising of the House of Representative and Senate are responsible for making laws for the good governance of Nigeria, while at the State level, the various States House of Assembly make laws for their respective States. The executive powers at the centre revolve around the President and those he might delegate same to; while at the States, it is the Governors that execute the laws made by the legislative arm. The power to interpret law which is the judicial power is vested in the judiciary made up of all the courts in Nigeria and headed by the Chief Justice of Nigeria. Above all, is the corresponding duty on the executive arm of government to obey court orders. These all important provisions of the constitution has been reaffirmed by the Supreme Court in the case of Joseph Amoshima $v$ The State (2011) , where the Court held thus:- 'the Appellant's Counsel should be reminded of the doctrine of separation of powers as enshrined in the 1999 Constitution. The Legislature is to enact laws while it is the duty of the Judiciary to interpret the laws as enacted....'

Justice as a phenomenon could mean the quality of being righteous, honesty, impartiality, fairness, sound reason, validity, rightfulness, upholding what is just and lawful, reward virtue and punishing of vice (Oputa, 2004). Therefore, justice is the pivot on which peace, harmony, security and economic development rotates. Thus, for the rule of law to thrive in any society, the notion of justice must be seen as being practiced.

The bane of the socio-political and economic problem in Nigeria today is the failure to strictly adhere to the doctrine of rule of law and notion of justice. Nigeria is an entity made up of numerous nations with cultural diversity. However, there are three major entities namely Hausa, Ibo and Yoruba.

2.2 The Nigerian entity and problems of justice and the rule of law

Nigeria as a political entity is bedeviled with a myriad of socio economic and political problems, which are inherently multifarious in nature (Ubeku, 1991). Some of these problems include but not limited to political instability or uncertainty, corruption (Musa, 1991), prison congestion, insufficient man power in the criminal justice sector, poverty, etc Nigerian as an entity is made up of over 250 ethnic groups with diverse language and cultural heritage all struggling to gain most recognition and fair share in the available national resources. These had led to the various crises inherent and which of course are the sources of insecurity, unrest and underdevelopment in the country. The causes of perceived injustice and lack of trust in Nigeria are:

The falsification and fraudulent creation of Nigeria by the colonial masters: Prior to the coming of the British Government, there was no such entity called Nigeria. However, individual ethnic group were autonomous and independent of one another. There was the Oyo Empire, Kanuri Empire, the Efik, Ogoni, Fulani, Hausa, Igbo, Tiv Kingdom, Bornu Kingdom etc. With the coming of colonial masters, these ethnic independent groups were divided into the Southern protectorate, Northern protectorate and the colony of Lagos. In 1914 and for administrative convenience and selfishness, Lord Lugard amalgamated the Southern, Northern protectorates and colony of Lagos into one entity christened by his wife as Nigeria without the prior consent and approval of the hitherto autonomous and independent ethnic groups.

These ethnic groups since then, have been forcefully staying together even after postindependence. The various Constitutions of Nigeria had not helped matters. The preamble of these Constitutions provides that: 'WE THE PEOPLE of the Federal Republic of Nigeria having firmly and solemnly resolved, TO LIVE in unity and harmony......' This preamble leaves questions such as: when did the various ethnic groups agree, where did they agree, what did they agree, under the supervision of who, etc. The fact that the creation of the entity called Nigeria was an imaginary and experimental work of the British Government makes an average Yoruba, Hausa or Igbo man to looks at himself first from his tribal perspective before seen 
himself as a Nigerian even at the expense of national security (Ayua \& Dakas, 2009).

Political crisis

Shortly after independence, Nigeria became engulfed in political crisis. Creation of political parties was based on ethnic inclination. For example, the Northern People's congress (NPC) led by Sir Ahmadu Bello who won election in the North, Action Group led by chief Obafemi Awolowo a Yoruba man held sway in the West, the National Council of Nigeria and Cameroon (NCNC) led by Dr. Nnamdi Azikiwe controlled the East, Igbo dominated area. This created unhealthy rivalry among the ethnic groups, there was allegations of corruption, destruction of lives and property. This led to distrust and skepticism among political leaders and their followers. Till date elections in Nigeria are not issue based but tribal, religion and characterized with violence.

The military prelude

The first military coup staged by five Revolutionary Officers and led by Major Chukwuma Kaduna Nzeagwu (Ademoyega, 1981), an Igbo man, is another main source of the crisis rocking Nigeria till date. It is on record that those killed in the said coup were mainly from the Northern and Western extraction leaving out those of Igbo origin. This led to the counter coup led by a Northerner and which claimed mostly the lives of those of Igbo origin, the attack and massacre of Igbo natives in the North, the disagreement between Yakubu Gowon and Odumegwu Ojukwu etc culminated into the civil war where several thousands of lives were lost; ever since, Nigerians have been treating themselves with suspicion (Ademoyega, 1981) . Even where there is a genuine and economically viable policy by the government, tribal and religious sentiments are read into it.

Constitutional problems

The 1999 Constitution of the Federal Republic of Nigeria as it is today is one of the sources of injustice in Nigeria. Taking a look at the 1999 Constitution, the following provisions need a rethink to wit:

i. The preamble of the 1999 Constitution

The preamble to the 1999 constitution is the first major problem characterized by deceit. It provides that: 'we the people of the Federal Republic of Nigeria, having firmly and solemnly resolved to live in unity and harmony as one indivisible and indissoluble sovereign Nation under God dedication.....'

The question that readily comes to mind is:when and where did the various ethnic tribes that were being referred to above sit to decide to or resolved to stay together. It is suggested that a sovereign national conference be organized whereat all stake holders, ethnic groups, civil societies, etc will draft a new constitution for Nigeria reflecting the true desire of the people.

ii. Fundamental objectives and directive principles of state policy

Chapter two of the Constitution deals with fundamental objectives and directive principles of state policy. It encompasses the political, economic, social, educational, foreign policy, environmental and cultural objectives. However, despite these noble provisions, S. 6(6) (c) makes these all important section not justiciable. This has led to misrule and lack of care for the masses. In Archbishop Anthony Okogie \&Ors. v A.G. Lagos State (1981), the Lagos State government enacted Education Law under which privately owned schools were closed The

Plaintiffs went to the court and obtained a declaration that the act of the Lagos State Government offended their constitutional right to own schools. The court held that the directive principles of state policy in Chapter 2 of the constitution have to conform to and run subsidiary to the fundamental rights provision in Chapter 4 of the then 1979 constitution and that chapter 2 is subject to legislative powers conferred on the State. Also the provision in item 60 of the exclusive legislative list, gives to the National Assembly power to make laws with respect to the establishment and regulation of authorities for Nigeria, to promote and enforce the observance of the fundamental objectives and directive principles in the Constitution.

iii. Federal character

The constitutional provision of federal character is another injustice created by the Constitution of Nigeria in section 14(3-4). This provision allows competence to be thrown to the wind while incompetence triumphs. The employment policy, admission policy and developmental policy is centered on federal character or quota system. The ugly incident that led to the case of Adeyinka Abosede Badejo v Minister for Education (1996) leaves much to be desired. This policy no longer serves as a unifying factor. Rather it breeds divisions, ethnicity and tribalism and ought to be reviewed.

iv. Failure to adhere to section 10 of the Constitution

By the provisions of section10 of the 1999 Constitution of Nigeria, the government of the Federation or of a State shall not adopt any religion as State Religion. The essence of this noble provision must have been to free Nigeria 
from religious crisis hence, the neutrality. However, Government at all tiers is so much involved in religious activities to the extent of sponsoring pilgrims to Mecca and Jerusalem to the detriment of other religions and at the expense of other pressing social amenities that will be of benefit to the generality of the public.

v. Failure in the administration of justice system

Apart from problems of corruption, lack of man power, delay and high cost of justice, overcrowded prisons and a host of other problems that have continuously characterized the Nigerian justice system, the problem of tribalism in the appointment of judicial officers responsible for the administration of justice is another evil of great concern to many. The Nigerian judicial apparatus has not been insulated from tribal consideration, political affiliation, religious inclination and influence; thus making it generally difficult for a fair application of the rule of law and justice.

vi. Weak and dependent judiciary

One obvious fact in the federal constitution of Nigeria is that the cherished principle of separation of power is entrenched in all the constitutions that have been used in Nigeria and it is also provided for the 1999 Constitution (as amended). However, a major problem confronting adherence to the rule of law and justice is the fact the judicial arm of government are not only weak in Nigeria but are not independent. The importance of the independence of the judiciary was reiterated by the court in the case of Eriobun v Obiora(1999) when the court held that: a judge by the nature of his position and professional calling is expected to be straight, forward, upright, diligent, consistent and open in whatever he does in court and in other places of human endeavor that he happens to find himself. This is because his character as a judge is public property. $\mathrm{He}$ is the cynosure of the entire adjudication in the court and like Caesar's wife of ancient Rome, he is expected to live above board and above all suspicion, if the judicial process should not experience an y reverse or suffer detriment. A judge should know that by nature of his persistency and judicial functions, he is consistently on trial for any improper conduct immediately before, during and immediately after the trial of the case. In year 2017, the Constitution was amended via the Constitution of the Federal Republic of Nigeria 1999 (Fourth Alteration,No.4) Act, 2017 and Act No.7. These alterations seek to provide for the funding of the judiciary directly from the consolidated revenue fund of the State by substituting for subsection (3) of Section 121 of the Principal Act which formerly read: "Any amount standing to the credit of the judiciary in the Consolidated Revenue Fund of the State shall be paid directly to the heads of the courts concerned" a new subsection (3) which now reads "Any amount standing to the credit of the -(a) House of Assembly of the State; (b) Judiciary in the Consolidated Revenue Fund of the State shall be paid directly to the said bodies respectively; in the case of the judiciary, such amount shall be paid directly to the heads of the courts concerned." Babalola (2019) has also called for a complete independence of the judiciary as provided under sections 4,5,6,120(3) and (121(3) of the 1999 Constitution of the Federal Republic of Nigeria. He went further to say that those who man the judiciary would be able to carry out their duties without fear or favour to enable them deliver judgments in all matters before them. In May 22 ${ }^{\text {nd }}, 2020$, President Buhari signed the Executive Order No. 10 of 2020 for the implementation of financial autonomy of State Legislature and State Judiciary and other Related Matters pursuant to S. 5 of the 1999 Constitution. As at the time of this work, this very important Executive Order is yet to be implemented by any State in Nigeria. This has led to strike embarked upon by the Judicial Workers' Union and supported by the Nigeria Bar Association.

vii. The Nigerian factor

Nigeria as an entity has a peculiar problem which will hinder, if not make nonsense of the Sustainable Development Goal 16. This problem is referred to as the Nigerian factor. This phrase generally refers to a peculiar ways of doing things in an abnormal way. It includes unhealthy practices such as corruption, nepotism, tribalism, ethnicity, etc (Ogunode, 2015). The National Judicial Policy recognizes that the greatest and most damaging challenge to the administration of justice is corruption. Judges and Prosecutors were fingered as corrupt in the empirical survey conducted by the National Bureau of Statistics in collaboration with the United Nations office on Drugs and Crime (UNODC) in 2019

3.0 Application and observance of the rule of law and justice in Nigerian since 1999

Theoretically, governance in the Nigerian context is based upon the foundation of the rule of law and justice. However, in practical terms the contrary obtains. This could be attributed to the Long military rule. Successive Nigerian leaders have always paid lip services to adherence to the Rule of law, notion of justice and constitutional 
provisions. In other climes where democracy is strongly rooted, independent and incorruptible judiciary/court system, professional Police and Armed Forces, cohesive and articulate civil society and vibrant private sector are what give democracy the beauty that it has and which endures it to those other hitherto totalitarian or autocratic societies (Efebeh, 2015).

The Nigerian Police, Armed Forces and other Para Military Agencies seems not to realize and appreciate the fact that Nigeria is now governed democratically. Hence, abuse of innocent citizens, brutalization and extra- judicial killings are still the order of the day. They even serve as willing tools of oppression for politicians in power against perceived opponents (Afeno, 2014). Commencing from 1999 to date, there had been flagrant disobedience to court orders, Unnecessary interference in the activities of other arms of government, disobedience to law and Gross violation of fundamental human rights, removal of judicial officers illegally etc. In fact President Buhari has since assuming office in 2015, shown an unprecedented disregard for the rule of law and human right by ignoring and disobeying court orders for at least 40 times(Olaniyan, 2019).

\subsection{CONCLUSION AND RECOMMENDATIONS}

The signing into law, the Executive Order No.10 of 2020 for the implementation of financial autonomy of state legislatures and state judiciary and other related matters on the $22^{\text {nd }}$ day of May, 2020 , is a noble act and the directive of the Nigerian Bar Association to her members is germane. All States government should as a matter of urgency implement this Order. Also, Kudos must be given to the Independent National Electoral Commission (INEC) who in recent times had been obeying Court orders regarding electoral matters even where such orders are against the ruling party. However, on the part of the Military, Police and para- military agencies, there need to be special reorientation tailored towards making all uniformed men imbibe the spirit, culture and doctrines of democracy. As it is today, government chooses which court order to obey and those to disobey. The cases of Col. Dansuki, Omoyele Sowore, El' Zakazaki and many others are examples of instances where courts' orders were disregarded; and in most cases is reluctant in obeying court orders. To achieve the aims of the Sustainable Development Goal 16, Government should as a matter of urgency adhere to the principle of separation of power and especially ensure the independence of the judiciary. The Attorney-General either at the State or Federal level need to live up to the expectations of their duties which among others include defending the Constitution. The 1999 Constitution should be amended in line with the observations raised above so as to reduce to its lowest minimum things and policies that divide Nigerians. The court in Arthur Yates \& Co. Pty. Ltd. v. Vegetable Seeds Committee (1945), held that: 'It is not the English view of the law that whatever is officially done is law ... On the contrary, the principle of English law is that what is done officially must be done in accordance with the law.'

Each and every Nigerian should be orientated to have at the back of their mind that the principle of Nigerian law is that what is done officially must be done in accordance with the law. This work concluded (to borrow the words of Asaju) that democracy thrives on a global concept known as rule of law. That concept works on the principle that everybody is subject to and accountable to the law as promulgated and openly accessible to all, government inclusive, Obedience to court orders, accountability to court, judicial autonomy and open government are part of the rule of law. More so, there is the need for a true constitutional conference devoid of government Intervention; where Federal Government will only provide enabling environment while the various ethnic groups should be allowed to choose their various representatives; whereat, all constitutional problems will be resolved, and the outcome of the said constitutional conference should be implemented.

\section{REFERENCES}

Ademoyega, A., 1981. Why We Struck: The Story of the First Nigerian Coup. Evans Brothers Nigeria Publishers Limited.

Afeno, S. O., 2014. Killings by the Security Forces in Nigeria: Mapping and Trend Analysis 2006-2014 at http://www.ifra.nigeria.org/IMG/pdf/killingby-security-forces-nigeria.pdf accessed on 20 March, 2021

Agbaje F., 1959. The Rule of Law and the Third Republic. Owoboye, Co (ed) Fundamental Legal Issues in Nigeria 1959. 
Aguda, T. M., 1985. A New Perspective in Law and Justice in Nigeria (Being the Distinguished Annual Lecture delivered at the National Institute on October 25, 1985)

Ali, Y., 2014. Governance and Sectorial Development in Nigeria. (Being a paper delivered at the Great Ife Alumni Association $21^{\text {st }}$ Biennial Convention lecture held at Great Oduduwa hall, OAU Ife on $23^{\text {rd }}$ May, 2014). at yusufali.net $>$ articles $>$... accessed 22 March, 2021.

Akeredolu. O. O., 2008. Rule of Law in Nigeria: Extant Profile and Challenges for the Bar. (Being the keynote Address presented at the biennial Law Week of the Nigerian Bar Association llorin Branch held between $14^{\text {th }}$ and $16^{\text {th }}$ of May, 2008)

Asaju, T. That Desecration of the Rule of Law. www.dailytrust.com.ng accessed on the 15 December, 2020

Ayua, I. K. and Dakas, C. J. D., 2009 Federal Republic of Nigeria. www.foundfed.org.>Book 1 accessed 18 October, 2020.

Azeez, B., 2019. Police Brutality in Nigeria. at http://www.opinionnigeria.com accessed on $5^{\text {th }}$ October, 2019,

Badamasiuy J. and Bello M., 2013. An Appraisal of Administrative Justice and Good Governance in Nigeria. Journal of Politics and Law, 6 (2)

Belton R. K., 2005. Competing Definition of Rule of Law: Implications for Practitioners. At www.CarnegieEndowment.org/pubs accessed 18 October, 2020.
Bodenheimer, E., 1962. Jurisprudence: The Philosophy and method of the law. USA Harvard University Press

Efebeh, E. V., 2015 'Democracy and the Rule of Law in Nigeria: 1999 - 2015, Research on Humanities and Social Sciences 5(20)

Kalu, A. and Osinbajo, Y. (eds), Perspectives on Corruption and Other Economic Crimes in Nigeria (Lagos: Federal Ministry of Justice: 1991)

Musa, S., 1991. "Anatomy of Corruption and Other Economic Crimes in Nigerian Public Life" In Kalu and Osinbajo, Perspectives on Corruption: and Other Economic Crimes in Nigeria (Lagos: Federal Ministry of Justice: 1991) pp.9496.

Nlerum, S. O. The Nigerian Factor and the Criminal Justice System" (Unpublished Paper: Senior Lecturer and Head, Dept of Jurisprudence and International Law Rivers State University of Science and

Technology Nkpolu, Port Harcourt, Nigeria) at www.nigerianlawguru.com $>$ accessed $25^{\text {th }}$ April, 2021

Ogunode, S. A., 2015. Criminal Justice System in Nigeria: For the Rich or the Poor? Humanities and Social Sciences Review, 4 (1) p 30

Olaniran, K., 2019. theeditor@punchng.org accessed on the 26 March, 2021

Oputa, C. A., 1989. The Crisis in the Rule of Law. Being a keynote address delivered at the 1989 annual general bar conference held at the Nigerian law school, Victoria Island, Lagos on Monday 28, August 1989. 
Oputa, C. A., 2004. Peace Justice and Fair May in a Democratic Nigeria. (Being a paper delivered as a birthday lecture in Honor of His Grace Most Rev. (Dr.) John O. Onalyekan. CON, The Catholic Archdiocese of Abuja on 31 January 2004.

Oputa, C. A., 1990. Judicial Ethics, Law, Justice and the Judiciary. Journal for Contemporary Legal Problems, 8

Rosenfeld M., 2001. The Rule of Law and the Legitimacy of Constitutional Democracy. Southern California Law Review, 17

Stayllon and Obasanjo, 'The Demise of the Rule of Law in Nigeria under the Military: Two parts of view', Ibadan University Press 1980.

Stein, R., 2009. Rule of Law: What Does it Mean?. Minnesota Journal of International Law 18( 2)

Ubeck, A. K., 1991. The Social and Economic Foundations of Corruption and Other Economic

Crimes in Nigeria," In Kalu, A. and Osinbajo, Y. (eds), Perspectives on Corruption and Other Economic

Crimes in Nigeria Lagos: Federal Ministry of Justice: 1991 pp.39, 41, 43. 